\title{
Achieving Green Building in Qatar through Legal and Fiscal Tools
}

\author{
Aaron Harmon ${ }^{1} \&$ Jon M. Truby ${ }^{2}$ \\ ${ }^{1}$ Clinical Assistant Professor and Affiliate Researcher, Centre for Law \& Development, College of Law, Qatar \\ University, Qatar \\ ${ }^{2}$ Associate Professor of Law and Director of the Centre for Law \& Development, College of Law, Qatar \\ University, Qatar \\ Correspondence: Jon M. Truby, Associate Professor of Law and Director of the Centre for Law \& Development, \\ College of Law, Qatar University, Qatar. E-mail: jon.truby@qu.edu.qa
}

Received: August 12, 2019

doi:10.5539/jsd.v12n5p96
Accepted: September 3, 2019

Online Published: September 29, 2019

URL: https://doi.org/10.5539/jsd.v12n5p96

\begin{abstract}
In the midst of both a multi-State blockade of Qatar and the urgency to complete major building projects in time to host the 2022 FIFA World Cup, the limits of Qatar's resource sustainability have been tested. The State of Qatar is the world's highest per capita consumer of water and emitter of CO2 emissions. Qatar is also at considerable risk of becoming an unlivable nation if the global temperature change targets of the Paris Agreement are breached. National law and policy seek to address this by promoting sustainability and focusing on reducing consumption, though such efforts are commonly overwhelmed by the enormity of the construction projects.

This article considers how the advancement of green building can provide multiple dividends in Qatar by enabling reduced resource consumption and producing less waste. LEED ${ }^{\circledR}$ certified "green" buildings consume between $10 \%$ and $25 \%$ less energy and $11 \%$ less water and emit $34 \%$ lower greenhouse gases than similar conventional buildings. The article analyses Qatar's law and policy approaches and available options. It further examines comparative law and policy models in the UK to explore how compatible such measures would be in Qatar. It concludes with possible legal and policy options available, assessing how effective such measures may work if transplanted into and/or adapted by Qatar.
\end{abstract}

Keywords: emissions, GCC, green building, LEED, sustainability, Qatar, water

\section{Introduction}

As the world's highest per capita consumer of water and emitter of $\mathrm{CO} 2$ emissions, Qatar is seeking to promote sustainable development as it grows. ${ }^{1}$ It is also a State with a vested interest in mitigating the effects of climate change, given the severe and irreversible changes that would make life in Qatar unlivable if temperatures exceed those specified in the Paris Agreement. ${ }^{2}$ With inefficient buildings being an overwhelmingly large contributing factor to a nation's emissions levels ( $40 \%$ in the EU), targeting this contributor with law and policy measures is a relatively effective way to mitigate climate change and over time. Such improvements can then be factored into the Nationally Determined Contributions ${ }^{3}$ in Qatar's Paris Agreement ${ }^{4}$ assessment report. $^{5}$

Qatar holds an opportunity for energy efficiency in residential homes, but few incentives ${ }^{6}$ or regulations exist for homeowners to make the necessary upgrades to their properties. Moreover, legal hurdles may in some cases

\footnotetext{
${ }^{1}$ This publication was supported by Qatar University Grant QUST-1-CLAW-2019-1. The findings achieved herein are solely the responsibility of the authors.

2 Jeremy S. Pal \& Elfatih A. B. Eltahir, "Future Temperature in Southwest Asia Projected to Exceed a Threshold for Human Adaptability,"

Nature Climate Change 6, pp. 197-200, http://dx.doi.org/10.1038/nclimate2833 (2016).

3 UNFCCC, "Nationally Determined Contributions (NDCs),"

https://unfccc.int/process/the-paris-agreement/nationally-determined-contributions/ndc-registry.

${ }^{4}$ UNFCCC Paris Agreement (2015) (as contained in the report of the Conference of the Parties on its twenty-first session, $\mathrm{FCCC} / \mathrm{CP} / 2015 / 10 /$ Add.1).

5 Jon M. Truby, “Using Bitcoin Technology to Combat Climate Change,” Nature Asia, doi:10.1038/nmiddleeast.2018.111 (2018).

${ }^{6}$ Jon M. Truby, Fiscal Tools for Inclusion of GCC States in the Global Environmental Programme: Focus Upon New Vehicle Imports, in Green Taxation and Environmental Sustainability (Edward Elgar, London) doi: 10.4337/9781781009024.00022 (2012).
} 
even preclude such investment. ${ }^{7}$ Using the United Kingdom as a model for green fiscal reform in this field, the purpose of this article is to demonstrate how other jurisdictions such as Qatar can achieve the triple benefit of lower emissions, ${ }^{8}$ reduced energy costs, and increased energy independence through such reforms. ${ }^{9}$ The paper demonstrates progress made and recommends reforms to ensure appropriate incentives are in place to incentivize a wide-scale program of green fiscal reform in the existing homes and new homes industry. It studies the situation in Qatar alongside that of the United Kingdom, in order to determine alternative incentive regimes best suitable for each jurisdiction. The intention is to advocate some legal and fiscal policy measures that would be suitable for Qatar if transplanted effectively or adapted according to national circumstances, as well as to determine which tools would not be suitable for Qatar. The results will be useful for both Qatar and states with similar economic, legal and social circumstances as Qatar, particularly other recently developed and GCC states that are seeking to optimize sustainability objectives.

\section{Background}

\subsection{National Background}

Qatar is an oasis in the Arabian Gulf. It is located on a tiny peninsula about the size of the state of Connecticut. ${ }^{10}$ Its only land border is shared with Saudi Arabia. Historically, most travel has occurred by air, and is now exclusively by air since Saudi Arabia permanently closed Qatar's only land border in December 2017. ${ }^{11}$ It is becoming increasingly well-known on the world stage, the owner of Qatar Airways and Al Jazeera, with a national sovereign fund heavily invested in countries such as the United Kingdom and United States. ${ }^{12}$ Qatar is a small country in terms of physical size (approximately 11,586 square kilometers). ${ }^{13}$ It has a combined population of approximately 2.7 million people, of which 85 to 90 percent are expatriates (expats). ${ }^{14}$

Life in Qatar is characterized by luxury and conspicuous consumption (for those who can afford it). Supercars, SUVs, and other high-end vehicles are relatively common on the roadways. Decadent brunches and fine restaurants are filled each week with expats and citizens alike. Air conditioning is nearly ubiquitous, to the point where it is not uncommon to see air-conditioned outdoor spaces and buildings with open doors in the middle of summer, when temperatures can exceed 115 to 122 degrees Fahrenheit (46 to 50 degrees Celsius).

The perception of abundance exists everywhere, though recycling is essentially non-existent. Everything is garbage, even easily recycled materials such as paper, tin, glass, and aluminum. It is easy to forget that Qatar produces little domestically and is heavily reliant on imports to satisfy its food, durable goods, and construction material needs. By some estimates, Qatar imports 95 to 99 percent of its food. ${ }^{15}$

\footnotetext{
${ }^{7}$ Jon M. Truby, "Regulating Sovereign Wealth Funds to Avoid Investment Protectionism," 1 Journal of Financial Regulation (Oxford), pp. 95-134, doi: 10.1093/jfr/fju002 (2015).

${ }^{8}$ Jon M. Truby, "VW's 'Defeat Devices' and Liability for Claims for Lost Emissions Tax Revenue, 1 Global Journal of Comparative Law, pp. 1-24, https://doi.org/10.1163/2211906X-00601001 (2017).

9 See also Jon M. Truby, "Financing and Self-Financing of SDGs Through Financial Technology, Legal and Fiscal Tools," in Sustainable Development: Harnessing Business to Achieve the SDGs through Financing, Technology and Innovation (Julia Walker, Alma Pekmezovic and Gordon Walker (eds.)) (Wiley: 2019) https://doi.org/10.1002/9781119541851.ch11; Jon M. Truby, "Decarbonizing Digital Currency: Law and Policy Insights for Reducing the Energy Consumption of Bitcoin and Blockchain Technologies," 44 Energy Research \& Social Science, pp. 399-410 (2018) https://doi.org/10.1016/j.erss.2018.06.009.

10 "Foreign Country Land Mass Compared to United States," https://www.insidervlv.com/landmass.html ("slightly smaller than Connecticut"); "Put the Size of Countries in Perspective by Comparing Them to US States," http://www.decisionsciencenews.com/2015/02/20/put-size-countries-perspective-comparing-us-states/.

${ }^{11}$ In fact, Saudi Arabia has recently revealed plans to dig a canal along the Qatar border, effectively turning the peninsula into an island. See "Saudi Arabia Eyes Up Canal Border Idea, Turning Qatar From A Peninsula Into An Island," Forbes,

https://www.forbes.com/sites/dominicdudley/2018/04/06/saudi-canal-qatar-island/\#765f9f8b249e (April 6, 2018).

12 "Qatar Airways CEO Says Company Fully Government Owned," Reuters,

https://www.reuters.com/article/qatar-airlines-idUSL6N0NR1KA20140505 (May 5, 2014); “The New Arab Media Phenomenon: Qatar's Al-Jazeera," Middle East Policy Council, https://www.mepc.org/journal/new-arab-media-phenomenon-qatars-al-jazeera (Summer 2001); Shibley Telhami, "The World Through Arab Eyes: Arab Public Opinion and the Reshaping of the Middle East," pp. 198-99 (2013); "Qatar Plans to Invest \$10 Billion in US Infrastructure,” Business Insider, https://www.businessinsider.com/qatar-to-invest-10-billion-in-us-infrastructure-2016-12 (December 13, 2016); “Qataris Own More of London than the Queen," The Telegraph, https://www.telegraph.co.uk/business/2017/03/17/qataris-london-queen/ (March 17, 2017).

13 “The World Factbook: Middle East: Qatar," United States Central Intelligence Agency, https://www.cia.gov/library/publications/the-world-factbook/geos/qa.html; "Best Countries," U.S. News and World Report, https://www.usnews.com/news/best-countries/qatar.

${ }^{14}$ Id.

15 "Hunger Games: The Geopolitics of the GCC's Food Insecurity," The New Arab, https://www.alaraby.co.uk/english/comment/2017/9/22/hunger-games-geopolitics-of-the-gccs-food-insecurity (September 22, 2017);
} 
Water seems to be in almost infinite supply, even though every drop of water in Qatar must either be imported or desalinated, which requires a substantial amount of energy to accomplish. ${ }^{16}$ Decorative plants that should not thrive in the heat are diligently irrigated and/or replanted each season. Cars are often washed in front of villas using hoses that freely spill gallons onto the driveways and sand. Although this is illegal (with severe fines up to QR 20,000 for noncompliance), limited enforcement means the practice continues. ${ }^{17}$

Qatar is the highest consumer of water per capita in the world, using four times more water per person than European households, and ten times more than other countries in the developing world. ${ }^{18}$ Electricity is cheap, free for citizens and heavily subsidized for expats. At night, the city is blanketed in light pollution from the streetlights and light shows playing across the skyscrapers of Doha's downtown.

Over the last forty years, Qatar has been undergoing a construction boom. Photos of Qatar in the mid-1970s bear little resemblance to more modern photos. ${ }^{19}$ Rapid expansion has been exacerbated by the looming World Cup to be hosted by Qatar in $2022 .^{20}$ As such, almost every part of the city is under heavy construction.

\subsection{Recent Developments: The Blockade of Qatar}

The aspirational rhetoric and concrete steps taken by the Qatari government to manifest those aspirations were put into a new light and took on a renewed sense of urgency in June of 2017, when a blockade was announced by Saudi Arabia, the United Arab Emirates, Bahrain, and Egypt, joined in spirit by several other countries in the region. The blockade continues as of the time of this publication and shows no signs of abating. ${ }^{21}$

Qatar's only land border, with Saudi Arabia, from which it received approximately $40 \%$ of its imports, was closed off. ${ }^{22}$ Qataris residing in those countries were expelled, and citizens of the blockading countries were recalled to their homes. ${ }^{23}$ Air space all around Qatar was cut off, and citizens and expats alike were initially barred from entering the blockading countries (expats were eventually allowed entry via non-blockading countries). ${ }^{24}$ Citizens of those countries were prohibited from expressing sympathy towards Qatar, risking harsh civil penalties or even imprisonment. ${ }^{25}$

"UPDATE 1 - Qatar Food Imports Hit After Arab Nations Cut Ties - Trade Sources," Reuters https://www.reuters.com/article/gulf-qatar-food-idUSL8N1J23IC (June 5, 2017).

16 “Water and Desalination," Hukoomi, http://www.hukoomi.qa/wps/portal/topics/Environment+and+Agriculture/wateranddesalination; M.A. Darwish \& Rabi Mohtar, "Qatar Water Challenges," Qatar Environment and Energy Research Institute, Qatar Foundation, http://wefnexus.tamu.edu/files/2015/01/Qatar_water_challenge_Journal_paper.pdf, (June 8, 2012).

${ }^{17}$ Law No. 20 of 2015, amending Law No. 26 of 2008.

18 "Qatar's Per Capita Water Consumption 'Highest in the World,"”

http://technicalreviewmiddleeast.com/power-a-water/water-a-environment/qatar-s-water-consumption-highest-in-the-world (March 7, 2013).

19 "Incredible Photos Show How Qatar Has Transformed Over 40 Years," Business Insider, https://www.businessinsider.com/doha-qatar-then-and-now-2014-2 (February 17, 2014); "20 Skylines Of The World: Then Versus Now," https://www.hongkiat.com/blog/world-skylines-then-now/.

${ }^{20}$ Jon M. Truby, "International Investment Law, Trade in Services and Customs: Legislative Strategies for States Hosting International Competitive Events," 12-1 Global Trade \& Customs Journal, pp. 39-45 (2017).

21 “As Qatar Prepares To Mark A Year Under The Saudi Embargo, It Looks Like The Winner In The Dispute,” Forbes, https://www.forbes.com/sites/dominicdudley/2018/05/17/as-qatar-prepares-to-mark-a-year-under-the-saudi-embargo-it-looks-like-the-winner -in-the-dispute/\#67379b1c7720 (May 17, 2018).

22 "Hunger Games: The Geopolitics of the GCC's Food Insecurity," The New Arab, https://www.alaraby.co.uk/english/comment/2017/9/22/hunger-games-geopolitics-of-the-gccs-food-insecurity, (September 22, 2017); "UPDATE 1 - Qatar Food Imports Hit after Arab Nations Cut Ties - Trade Sources," Reuters https://www.reuters.com/article/gulf-qatar-food-idUSL8N1J23IC (June 5, 2017).

23 "Expulsion of Qataris from Gulf States Comes into Effect," Al Jazeera, https://www.aljazeera.com/news/2017/06/expulsion-qataris-gulf-states-effect-170619122310181.html (June 19, 2017); “Qatar Blockade Case to Appear Before UN's Highest Court," Al Jazeera,

https://www.aljazeera.com/news/2018/06/qatar-blockade-case-international-criminal-court-180627081742617.html (June 27, 2018).

24 “Qatar, Cut Off From Neighbors, Remains Defiant,” Wall Street Journal,

https://www.wsj.com/articles/qatar-cut-off-from-neighbors-remains-defiant-1521106201 (March 15, 2018); “Qatar Accuses UAE, Bahrain Over New Airspace Violations," The New Arab,

https://www.alaraby.co.uk/english/news/2018/3/10/qatar-accuses-uae-bahrain-over-new-airspace-violations (March 11, 2018); “4 Arab

Countries Cut Off Flights To/From Qatar Over 'Terrorism'; No US Action Yet,” JDA Journal,

https://jdasolutions.aero/blog/qatar-airways-suspended/ (June 6, 2017).

25 "Media Blocked, Threatened in Dispute with Qatar," Human Rights Watch,

https://www.hrw.org/news/2017/06/14/media-blocked-threatened-dispute-qatar (June 14, 2017); "Bahrain and UAE Criminalize 'Sympathy' for Qatar," The Washington Post,

https://www.washingtonpost.com/world/national-security/bahrain-and-uae-criminalize-sympathy-for-qatar/2017/06/08/ce74a666-4c70-11e7- 
In response, Qatar was required to make alternative arrangements to import food and other supplies from countries such as Turkey and Iran, at costs estimated to be substantially higher than previous expenditures. ${ }^{26}$ Qatar "spent into the problem," and heavily subsidized the increased expenditures in order to reduce the impact on its population. ${ }^{27}$ Still, the effects of the embargo have been felt, most so among its most vulnerable low-income populations. Hotels and construction companies have even taken measures such as putting employees on extended unpaid leaves in order to address the reduced supply and demand issues. ${ }^{28}$

Against this backdrop, the subject of resource conservation and construction is ripe for reconsideration. The blockade has presented hardships and incredible costs for the government and residents of Qatar. At the same time that it presents a sober reminder of Qatar's vulnerabilities, it has also likely created a new openness to and sensitivity for solutions designed to achieving those goals and, as a result, to achieving a heightened sense of national security and self-reliance.

\section{Qatar Sustainability Objectives}

Although it may not appear to be the case to a casual observer, resource independence has long been a priority for Qatar. Sustainability and conservation of natural resources has been identified as instrumental to national security in guiding documents such as Qatar National Vision 2030 ("QNV 2030") and the Qatar National Development Strategy ("QNDS"). ${ }^{29}$ The Emir of Qatar, Sheikh Tamim bin Hamad bin Khalifa Al Thani, has stated that "[w]ise political leaders know the direction in which they would like their societies to develop, balancing the interests of present and future generations....The welfare of our children, and of our children yet to be born, demands that we use our resource-wealth wisely." 30 Additionally, green construction has been mandated for certain development projects by regulations in the 2014 Qatar Construction Specifications ("QCS").

The $\mathrm{COP}^{31} 18$ UN Framework Convention on Climate Change ${ }^{32}$ conference in December 2012, hosted in Doha, highlighted the importance placed by Qatari policymakers on achieving a global sustainable solution to climate change. Events aimed at protecting Qatar's environment and informing the public about environmental issues are increasingly common, demonstrating it to be a priority area for the State in its rapid development and drive for sustainability. ${ }^{33}$

Indeed, Qatari law requires governmental bodies to educate the public and businesses on environmental issues, ${ }^{34}$ whilst Qatari education authorities have a statutory requirement to provide education on the environment in every

9669-250d0b15f83b_story.html?noredirect=on\&utm_term=.30820ab6689a (June 8, 2017); "Bahrain Says it will Jail Qatar Supporters for Up To Five Years," The Telegraph, https://www.telegraph.co.uk/news/2017/06/08/bahrain-says-will-jail-qatar-supporters-five-years/ (June 8, 2017).

26 “"The Severity of the Dispute is Unprecedented”: Qatar Has Spent $\$ 40$ Billion Countering the Saudi-Led Blockade,” Business Insider, https://www.businessinsider.com/qatar-blockade-cost-moodys-saudi-arabia-2017-9 (September 14, 2017) ("Although alternative trade arrangements have been made with Turkey and Iran, the [Moody] report estimated Qatar is now paying ten times more to import food and medicine than before sanctions were imposed.”).

${ }^{27}$ Id.

28 "Qatari Companies Send Workers On Unpaid Extended Leave As Gulf Crisis Continues," Migrant Rights,

https://www.migrant-rights.org/2017/08/qatari-companies-send-workers-on-unpaid-extended-leave-as-gulf-crisis-continues/ (August 6, 2017); “Qatar Crisis: Migrant Workers Sent on 'Unpaid Extended Leaves’ as Business Slumps,"

https://www.ibtimes.co.in/qatar-crisis-migrant-workers-sent-unpaid-extended-leaves-business-slumps-737559 (August 7, 2017); "Report:

For Some Qatar Employees, Blockade Hits Hard,” Doha News, https://dohanews.co/report-for-some-qatar-employees-blockade-hits-hard/ (August 7, 2017).

${ }^{29}$ General Secretariat for Development and Planning, Qatar National Vision 2030, Pillar 4

https://www.mdps.gov.qa/en/qnv/Documents/QNV2030_English_v2.pdf (2008); General Secretariat for Development and Planning, Qatar National Development Strategy 2011-2016, Chapter 6,

https://www.mdps.gov.qa/en/knowledge/HomePagePublications/Qatar_NDS_reprint_complete_lowres_16May.pdf.

${ }^{30}$ General Secretariat for Development and Planning, Qatar National Vision 2030, Foreword

https://www.mdps.gov.qa/en/qnv/Documents/QNV2030_English_v2.pdf, (2008).

${ }^{31}$ Conference of the Parties.

32 18th Session of COP 18 to the UNFCCC and the 8th Session of the Meeting of the Parties to the Kyoto Protocol, to review the implementation of the Kyoto Protocol and take decisions to promote its effective implementation, which took place from November 26, 2012 to December 7, 2012 in Doha, Qatar; http://www.cop18.qa/en-us/aboutcop18cmp8/cop18cmp8.aspx.

${ }_{33}$ See, e.g., Ministry of Environment of Qatar, Qatar International Environment Protection Exhibition \& Conference, http://www.essb.de/images/ecoq/ecoQ_e-Brochure.pdf; Qatari Diar Supreme Committee for Delivery and Legacy, Sustainability Summit 2019, https://www.sustainabilitysummit.qa/.

${ }^{34}$ This is one of the duties of the Supreme Council for Environment and Natural Reserves (established by Law No. 11 of 2000). 
curricula at all teaching stages. ${ }^{35}$ Sustainable development and the protection of natural resources are issues mandated by the Constitution of Qatar, further highlighting its significance. ${ }^{36}$ This is reinforced by environmental and renewable energy research goals being listed as the first objective in Qatar's National Research Strategy ("QNRS"), ${ }^{37}$ as well being prioritized in the QNDS ${ }^{38}$ and QNV 2030. ${ }^{39}$ Qatar has also committed to the UN's Sustainable Development Goals, of which Goal 11 focuses upon sustainable cities and communities.

Qatar is not alone in the region on this issue, with states across the $\mathrm{GCC}^{40}$ facing similar environmental issues and adaptations in their law and policy favoring sustainable development and environmental protection. ${ }^{41}$ In line with the goals of the GCC region, Qatar has bold plans to diversify its economy, protect the environment, and implement a sustainable development policy, as expressed through the QNDS and other dicta. One of its stated budgetary aims is to be able to fully finance the State budget from non-hydrocarbon revenues by 2020, though the International Monetary Fund has emphasized that more effort needs to be carried out for Qatar to realize this objective. ${ }^{42}$ A fundamental problem in the implementation of both the QNDS and QNRS is the limited academic literature available to researchers developing solutions to achieve these national strategies.

Qatar's vulnerability to hydrocarbon price fluctuations is a major reason underlying the push for diversification. ${ }^{43}$ Planning Area 1 of the QNRS substantially covers the issue of developing a sustainable ${ }^{44}$ and diversified $^{45}$ low-emissions ${ }^{46}$ energy base in Qatar. The planning areas largely focus upon renewable energy and particularly solar energy. Additionally, QNRS Objective 2.1 calls for the "implementation of a solar energy research program. ${ }^{, 47}$

QNRS Objective 3.1 requires research into energy efficiency, specifically through smart grid technologies. All of the objectives under QNRS Planning Area 1 are related to the overall national concerns of ensuring both future energy production and an effective response to climate change, as outlined in QNRS Objective 6. Qatar has further been directed to research solar energy through Priority Topic 4 of RAND's "Recommended Research Priorities for the Qatar Foundation's Environment and Energy Research Institute" through collaborative research. ${ }^{48}$

Alongside the QNRS, two of the pillars of QNV 2030 relate specifically to these research areas. The Fourth Pillar of QNV 2030 focuses on environmental development, and seeks to "ensure harmony among economic growth, social development and environmental protection." ${ }^{49}$ The Third Pillar focuses on economic development, and is the basis of the national call for diversification in energy production as expressed in the QNV 2030 ${ }^{50}$ QNV 2030 seeks for Qatar to build "a diversified economy that gradually reduces its dependence on hydrocarbon industries, enhances the role of the private sector and maintains its competitiveness." ${ }^{51}$ QNRS recognizes that a means to achieve this involves initial research into energy diversification, renewable energy and, in particular, solar energy. Other Gulf states mirror this objective, as noted in the QNDS, stating "[a]mong [GCC] countries, Bahrain and

\footnotetext{
${ }^{35}$ Law No. 30 of 2002 on Environmental Protection, Art. 7.

${ }^{36}$ Constitution of Qatar, Arts. 29, 33.

${ }^{37}$ Launched at the 2012 Joint Qatar Foundation Annual Research Forum and Arab Expatriate Scientists Network Symposium http://www.qf-research-division.org/images/QNRS_2012.pdf (2012).

${ }^{38}$ General Secretariat for Development and Planning, Qatar National Development Strategy 2011-2016, https://www.mdps.gov.qa/en/knowledge/HomePagePublications/Qatar_NDS_reprint_complete_lowres_16May.pdf. ${ }^{39}$ Id.

${ }^{40}$ Cooperation Council for the Arab States of the Gulf, including Bahrain, Kuwait, Oman, Qatar, Saudi Arabia and the UAE.

${ }^{41}$ See, e.g., the United Arab Emirates' Federal Environment Agency, https://www.ead.ae/en/portal/environmental.laws.aspx, and the Emirati Environmental Research and Wildlife Development Agency, founded pursuant to Law No. 4 of 1996.

42 “Qatar: Selected Issues,” International Monetary Fund, IMF Country Report No. 12/19, p. 11, http://www.imf.org/external/pubs/ft/scr/2012/cr1219.pdf (2012).

43 “Qatar: Staff Report for the 2011 Article IV Consultation,” International Monetary Fund, p. 23 (2011).

${ }^{44}$ QNRS Objective 5 specifically covers sustainability research. QNRS Objective 1 calls for "responsible exploration of natural resources."

${ }^{45}$ QNRS Objective 1.2 requires research into diversification.

${ }^{46}$ QNRS Objective 6.1.

${ }^{47}$ QNRS Objective 2.1.

${ }^{48}$ Kalra, Nidhi, Obaid Younossi, Kristy N. Kamarck, Sarah Al-Dorani, Gary Cecchine, Aimee E. Curtright, Chaoling Feng, Aviva Litovitz, David R. Johnson, Mohammed Makki, Shanthi Nataraj, David S. Ortiz, Parisa Roshan and Constantine Samaras, "Recommended Research Priorities for the Qatar Foundation's Environment and Energy Research Institute," pp. 58-69 (RAND Corporation, Santa Monica, CA), http://www.rand.org/pubs/monographs/MG1106 (2011).

${ }^{49}$ Qatar National Development Strategy, op. cit. n. 29.

${ }^{50}$ Id.

${ }^{51}$ Id.
} 
Saudi Arabia are working on strategies for encouraging more diverse economies. Abu Dhabi also has a comprehensive plan. ${ }^{, 52}$

The QNDS is particularly concerned with developing knowledge in managing scarcity. Water sustainability and security is considered highly essential within the QNDS, ${ }^{53}$ and include topics from free water subsidies for nationals $^{54}$ to territorial disputes. In particular, an overall target calls for legal reform, requiring initial legal study and research, to enact the National Water Act as described:

Qatar will enact a comprehensive National Water Act establishing an integrated system of quality requirements, discharge controls and incentives for conservation-in place of today's fragmented system of laws and regulations. The goal is a set of policies and regulations for the government to align consumption and supply over time while protecting water quality. ${ }^{55}$

Legal issues related to biodiversity in water in Qatar are also under-researched, and called for in both the QNDS ${ }^{56}$ and the QNRS. ${ }^{57}$ Furthermore, the QNDS recognizes that Qatar's "[g]overnment will be making critical decisions on uses of water" and requires evidence-based decision-making on this issue. ${ }^{58}$ Developing such knowledge therefore contributes to Qatar's stated policies for improving governance. ${ }^{59}$

\section{International Green Building}

Globally, the construction industry is perhaps one of the largest areas where large-scale sustainability gains can be accomplished. The built environment is inescapable. Everyone needs places to live and to work. And as a result, construction, habitation, maintenance, operation, and demolition of the built environment is responsible for a disproportionate amount of resource consumption.

The United Kingdom and the United States are both relatively populous and have led the charge towards high-performance real estate development. The United States Green Building Council (USGBC) estimates that buildings are responsible for $41 \%$ of energy use and $73 \%$ of electricity consumption. ${ }^{60}$ They also consume about $14 \%$ of all potable water (15 trillion gallons annually). ${ }^{61}$ Buildings are also responsible for about $38 \%$ of all $\mathrm{CO} 2$ emissions. ${ }^{62}$ The U.S. Environmental Protection Agency estimates that building demolition and construction in the U.S. created 170 million tons of waste in $2003 .{ }^{63}$ Globally, buildings consume approximately $40 \%$ of all raw materials. ${ }^{64}$

High performance ("green”) buildings consume less energy and water and use resources more efficiently. As a result, they also reduce $\mathrm{CO} 2$ emissions. LEED ${ }^{\circledR}$ certified buildings consume between $10 \%$ and $25 \%$ less energy and $11 \%$ less water and emit $34 \%$ lower greenhouse gases than similar conventional buildings. ${ }^{65}$ As a result,

\footnotetext{
${ }^{52}$ Id. at p. 96.

${ }^{53}$ QNDS, op. cit. n.29, “Cleaner Water and Sustainable Use," at p. 216.

54 "Qatar: Staff Report for the 2011 Article IV Consultation," International Monetary Fund (2011) at p. 23.

${ }^{55}$ QNDS, op. cit. n. 29, at p. 21; QNDS, op. cit. n. 29, at p. 21; QNDS, op. cit. n. 29, at p. 21; QNDS, op. cit. n. 29, at p. 220.

56 “Nature...conserved, protected and sustainably managed.” QNDS, op. cit. n. 29, at pp. 216-26.

${ }^{57}$ Qatar National Research Strategy 2012, Goal EE.4-Understanding and protecting Qatar's natural environment; Objective EE.4.1: Understand and, where appropriate, restore Qatar's marine and terrestrial natural resources, https://www.qnrf.org/Portals/0/QNRS 2012.pdf.

${ }^{58}$ QNDS, op. cit. n. 29, at p. 232.

${ }^{59}$ QNDS, op. cit. n. 29, at p. 230

60 “Three Billion Square Feet of Green Building Space LEED®-Certified,” U.S. Green Building Council, https://www.usgbc.org/articles/three-billion-square-feet-green-building-space-leed\%C2\%AE-certified (April 8, 2014); "Buildings Energy Data Book. Buildings Share of Electricity Consumption/Sales," Department of Energy, https://openei.org/doe-opendata/dataset/buildings-energy-data-book (2011).

61 “Benefits of Green Building,” U.S. Green Building Council, https://www.usgbc.org/articles/green-building-facts (April 1, 2016).

${ }^{62}$ U.S. Green Building Council, op. cit. n. 59; "Assumptions to the Annual Energy Outlook," Energy Information Administration, https://www.eia.gov/outlooks/aeo/assumptions/ (2008).

63 "Sustainable Management of Construction and Demolition Materials," U.S. Environmental Protection Agency, https://www.epa.gov/smm/sustainable-management-construction-and-demolition-materials; "Estimating 2003 Building-Related Construction and Demolition Materials Amounts," U.S. Environmental Protection Agency,

https://www.epa.gov/sites/production/files/2017-09/documents/estimating2003buildingrelatedcanddmaterialsamounts.pdf (March 2009).

${ }^{64}$ David Malin Roodman and Nicholas Lenssen, "Worldwatch Paper 124: A Building Revolution: How Ecology and Health Concerns are Transforming Construction" (Worldwatch Institute), http://www.worldwatch.org/node/866 (1995).

65 U.S. Green Building Council, op. cit. n. 61
} 


\section{LEED ${ }^{\circledR}$ buildings have led to a reduction of $34 \%$ of total U.S. CO2 emissions. ${ }^{66}$}

Globally, buildings consume approximately $40 \%$ of all raw materials. ${ }^{67}$ In the United States, LEED ${ }^{\circledR}$ projects have diverted 80 million tons of waste from landfills. ${ }^{68}$ Moreover, these buildings require between $11 \%$ and $19 \%$ less in maintenance costs, and occupants report being $27 \%$ more satisfied. ${ }^{69}$ Green building owners have reported decreased operating costs and increased the value of their assets. ${ }^{70}$

Early adopters of green building strategies were often motivated by ecological considerations and a certain level of idealism. Since technologies were not yet fully developed, materials were more difficult to source and stakeholders in the process lacked expertise in planning and executing such projects. Occupants of green buildings were also less familiar with the benefits of such tenancy and the related specialized requirements for operations and maintenance. As a result, it cost more to complete a green construction project, and owners were less likely to maximize lower operating costs and increased asset value.

As the number of green projects have increased, the market has adjusted to meet the increased demand. Companies have emerged to provide specialized services and further develop technologies. Certified professionals and experienced project managers have increased, more sophisticated modeling software has been developed, and the process of construction has been streamlined. Materials required for green and high-performance construction are also more widely available. As a result, the initial costs of constructing or retrofitting green buildings has been substantially reduced. ${ }^{71}$ In some cases, green construction costs the same as conventional construction. ${ }^{72}$

And as a result of increased tenant sophistication and discernment, coupled with lower operations costs, the real estate market has evolved to the point that "conventional" construction is a misnomer. Green building is becoming increasingly "conventional," and non-green building is becoming increasingly obsolete.

In some markets, the demand for green building has been stimulated by incentives such as tax credits, rebates, grants, expedited building permits, preferential zoning, reduced or waived fees, and increased floor to area ratios. ${ }^{73}$ In the United States, project stakeholders have been able to access both federal and state incentives (which in some markets are significantly more generous than federal subsidies). In both cases, the goal of these programs was to increase the amount of green building stock. In turn, consumer demand has created a premium for green buildings and lowered rental and resale values for conventional buildings.

Residential dwellings make up a substantial percentage of the built environment. However, much of the research and scholarship on green building has focused on commercial spaces rather than residential spaces. That has been changing in recent years. And with good reason, as tenants of green commercial spaces have increasingly sought to realize similar benefits in their personal dwellings. In the United States, there are a number of federal and state incentives to encourage developers to shift to green strategies for new developments. There are also a number of incentives for homeowners to retrofit existing dwellings with high-performance features. Additionally,

${ }^{66}$ Rob Watson, "Green Building and Market Impact Report 2011,"

https://www.greenbiz.com/research/report/2011/11/07/green-building-market-and-impact-report-2011 (2011).

${ }^{67}$ Roodman and Lenssen, op. cit. n. 64.

${ }^{68}$ U.S. Green Building Council, op. cit. n. 59.

69 “Green Building Facts,” U.S. Green Building Council, https://www.usgbc.org/Docs/Archive/General/Docs18693.pdf.

${ }^{70}$ McGraw-Hill Construction, "World Green Buildings Study" (2012).

71 "Green Building Costs and Savings,” U.S. Green Building Council, https://www.usgbc.org/articles/green-building-costs-and-savings (“A 2007 public opinion survey conducted by the World Business Council for Sustainable Development found that respondents believed, on average, that green features added $17 \%$ to the cost of a building, whereas a study of 146 green buildings found an actual average marginal cost of less than 2\%."); "Frequent Questions," U.S. Environmental Protection Agency,

https://archive.epa.gov/greenbuilding/web/html/faqs.html, ("Perhaps surprisingly, good green buildings often cost only a few percentage points or no more to build than conventional designs. Integrated design processes that identify the most efficient, holistic approaches to building green can reduce these initial costs. For example, in some cases, when buildings are carefully designed to be energy efficient, heating/ventilation/air conditioning (HVAC) equipment can be downsized for significant savings. There are also many green products and materials that cost the same or even less than conventional ones.").

72 Stuart D. Kaplow, "Green Building Costs Less Than Conventional Building,"

http://www.ajhon.com/images/Green_Building_Costs_Less_Than_Conventional_Building.pdf (June 2010); Desiree Hanford Green, "Do Green Buildings Cost More?,"

https://www.facilitiesnet.com/green/article/Do-Green-Buildings-Cost-More-Facilities-Management-Green-Feature--8954 (June 1, 2008 ); Janelle Penny, "Are Green Buildings Truly Cost-Effective? Can They Really Be Cheaper Than Conventional Buildings?,"

https://www.buildings.com/article-details/articleid/13745/title/the-cost-of-green-buildings (March 20, 2012).

73 "Business Case for Green Building," U.S. Green Building Council, https://www.usgbc.org/articles/business-case-green-building (February 10, 2015). 
lower maintenance and operations costs create the same incentives for renters and homeowners as for tenants of commercial spaces.

In Qatar, construction is booming in both the commercial and residential sectors. The country has been in a construction expansion for the past forty years. With the FIFA World Cup 2022 deadline looming, it is inevitable for major construction projects to continue at least until then.

As such, Qatar is in an enviable position. Unlike most markets, where new construction projects are less common, most of Qatar's real estate development market involves new construction. It is therefore in a position to make decisions about what its building stock looks like in the future. The decisions it makes now will affect the country for many years to come.

Moreover, the governmental structure is uniquely positioned to take the lead in steering the country's development toward sustainable building. Unlike a representative democracy or republic, which must contend with many competing interests and voices, the Qatari government is centralized. A strong executive branch that is very much in control of the policies affecting the country's development. As such, any desire to facilitate policy changes can be quickly and unilaterally implemented.

\section{Implementing Green Building Policy in Qatar}

\subsection{Progressive Measures}

As stated above, green building has been an increasing priority for Qatar. QNV 2030 and the QNDS both explicitly incorporate sustainability principles. ${ }^{74}$ Additionally, Qatar was one of the first countries in the Middle East to establish a Green Building Council chapter to promote LEED ${ }^{\circledR}$ certified projects and education. It has also independently developed one of the region's premiere green building certification systems, the Qatar Sustainability Assessment System (which later became the Gulf Sustainability Assessment System and is now the Global Green Sustainability Assessment System, or GSAS).

Significantly, Qatar has hardwired green building into the latest iteration of the Qatar Construction Specifications (QCS), and has mandated achievement of certain sustainability benchmarks in all new government construction projects. ${ }^{75}$ Some large development projects have voluntarily incorporated green building technologies, most notable being the Lusail City projects, Qatar Rail (metro), the World Cup 2022 stadiums, the Ashghal projects (schools \& mosques), and the new port and navy base. ${ }^{76}$

Qatar has also been making inroads into developing the residential green building market. In 2012 the Qatar Green Building Council developed the region's first Passivhaus experiment, in partnership with Qatar General Electricity \& Water Corporation (Kahramaa) and Barwa Real Estate Company, supported by engineers from Texas A\&M University at Qatar (TAMUQ) ${ }^{77}$ A villa with sustainability features was developed next to a villa utilizing conventional construction features. Two similar families were moved into each villa. The operating expenses and resource construction of each villa were monitored. During the winter, the passive house generated surplus electricity, which was fed back into the electricity grid. ${ }^{78}$

Qatar's National Development Strategy has targets on green building, including the implementation of a green building code to improve efficiency in construction design which would include standards for "elements as better

\footnotetext{
${ }^{74}$ Qatar National Vision 2030, op. cit. n. 29.

${ }^{75}$ Qatar Construction Specifications 2014, Section 7, "Green Constructions."

76 "Qatar to Top MENA in Green Buildings by 2030," The Peninsula,

https://www.thepeninsulaqatar.com/article/28/09/2016/Qatar-to-top-Mena-in-green-buildings-by-2030 (September 28, 2016); "Qatar Building Green Stadiums,” FIFA, https://www.fifa.com/worldcup/news/qatar-building-green-stadiums-2848542 (November 7, 2016); "Building Towards Green Stadiums at the 2022 FIFA World Cup ${ }^{\text {TM }}$," Supreme Committee for Delivery \& Legacy,

https://www.sc.qa/en/news/building-towards-green-stadiums-at-2022-fifa-world-cup (November 7, 2016); "Qatar Rail and Qatar Solar Technologies to Target Solar Energy Opportunities," Qatar Rail,

https://www.qr.com.qa/English/Media/News/Pages/Details.aspx?NewsID=114 (July 23, 2014); "New Port Project,” Hamad Port Project, http://www.npp.com.qa/120530_New\%20Port\%20Project\%20-\%20Mr.\%20Nabeel\%20AL\%20Buenain\%20for\%20MEED\%20FINAL\%20p df.pdf (May 30, 2012).

77 “The Strange and Sad Story of Qatar's First Passivhaus," Qatar Green Building Council,

http://www.eugcc-cleanergy.net/sites/default/files/events/2-3May2017QNRF/03.05.2017_session_ii_3_alex_amato_qgbc.pdf (May 3, 2017); "Passivhaus Experiment Prepares to Receive the Human Element," Qatar Foundation,

https://www.qf.org.qa/content/qf-telegraph/issue-118/passivhaus-experiment-prepares-to-receive-the-human-element (September 11, 2014); "Qatar to Top MENA in Green Buildings by 2030," The Peninsula,

https://www.thepeninsulaqatar.com/article/28/09/2016/Qatar-to-top-Mena-in-green-buildings-by-2030 (September 28, 2016).

78 "Qatar to Top MENA in Green Buildings by 2030," The Peninsula,

https://www.thepeninsulaqatar.com/article/28/09/2016/Qatar-to-top-Mena-in-green-buildings-by-2030 (September 28, 2016).
} 
insulation and increased shading and reflection."79 Following the introduction of "The Qatar Sustainability Assessment System for Green Buildings" which would apply to public buildings, it is also intended to subsequently include residential and commercial new-builds. ${ }^{80}$

\subsection{Limitations}

That said, many market-based incentives that have led to increased green building development in other markets do not exist (or do not exist to the same extent) in Qatar. While government policymaking is centralized in the executive branch and owners of projects are predominantly Qatari, other stakeholders in the process are diffuse. Many different organizations and individuals from multiple countries are involved in the planning and execution of development projects. This leads to non-uniform approaches to development, even within the same project or region. Similarly, there is currently no uniform system for sourcing materials.

Development contracts are often not negotiated by lawyers, as is the case in many other countries. Instead, standard FIDIC forms are used for development agreements, which utilize customized addendums to make up the heart of a particular project. Given the lack of a tort system, the risk management leverage between owners, developers, and contractors that exists in other markets does not exist (or not to the same extent) in Qatar. ${ }^{81}$

The current actual (or perceived) lack of building stock allows for inflated rental or purchase prices, regardless of the quality of the construction or the cost of operating and maintaining the facility. This is exacerbated by the fact that expat residents are only allowed to purchase property in certain parts of the country. In all other parts, expats are required to rent or live in facilities provided by their employer (which the employer either owns or leases from an owner).

Given the inelasticity of demand, owners are able to externalize operating costs almost exclusively to tenants. As such, there is no incentive on the owner's part to voluntarily incorporate green building features. On top of that, low utility prices and lack of property and personal income taxes remove the tax credit and rebate incentives that exist in other markets to voluntarily adopt green building strategies.

Finally, and particularly in the case of residential projects, some developments are built for obsolescence. Rather than build developments that incorporate higher-performance features, some projects are built under the assumption that after a certain number of years they will be demolished, cleared, and replaced with new construction. In these cases, the assumption seems to be that the costs of demolishing an existing development will be less than the costs associated with building green in the first place.

As such, there are institutional and market-based obstacles towards voluntary adoption of higher standards for residential development projects. Leverage mechanisms and incentives that exist in other markets do not exist (or not to the same extent) in Qatar. In the absence of governmental mandates, the challenge presented to policymakers is how to create incentives for developers and other stakeholders downstream to incorporate high performance features into residential construction projects.

\subsection{Setting Standards for Sustainable Construction}

In the absence of opportunities to provide incentives such as tax credits and rebates, and given the ability for owners to currently externalize costs to the end user ${ }^{82}$ one possible solution involves using penalties that focus on owners who do not achieve certain sustainability benchmarks in their projects. Another possible solution involves incorporating a "cradle to grave" approach to analyzing development projects, creating incentives for owners to develop higher quality projects and to retrofit existing projects.

Qatar has passed several laws that provide the foundation for such environmental policies. Law by Decree No. 30 of 2002, "Promulgating the Environmental Protection Law" provides general statements of policy as well as procedures and guidelines on broad thematic areas such as air, water, hazardous waste, the marine environment, and pollution prevention and response. It also provides general guidelines for environmental impact assessments (EIAs). Executive By-Law No. 4 of 2005 for the Environmental Protection Law details the procedures associated with the permitting system for all aspects of environmental management.

\footnotetext{
${ }^{79}$ Business Insider, op. cit. n.29, at p. 85.

${ }^{80}$ Business Insider, op. cit. n.29, at p. 222.

${ }^{81}$ See also Sachin Kerur and William Marshall, "Identifying and Managing Risk in International Construction Projects," International Review of Law 2012:8, http://dx.doi.org/10.5339/irl.2012.8 (2012).

82 On the socialization of environmental costs, see Jon M. Truby "Towards Overcoming the Conflict between Environmental Tax Leakage and Border Tax Adjustment Concessions for Developing Countries," 12 Vermont Journal of Envtl. Law pp. 149-83, http://vjel.vermontlaw.edu/files/2013/06/Towards-Overcoming-the-Conflict-Between-Environmental-Tax-Leakage-and-Border-Tax-Adjust ment-Concessions-for-Developing-Countries.pdf (2010).
} 
However, nothing in these laws provides direct guidance with regard to construction (outside of initial permitting and site management during construction). Filling this gap, more specific construction requirements are found in the Qatar Construction Specifications (the most recent iteration published in 2014). The QCS provide general construction standards, as well as minimum requirements \& specifications acceptable to the MoE and other local authorities. QCS standards are based on international standards (e.g., ASHRAE, ASTM, BS, ISO).

The QCS first incorporated a section on green construction in 2010. Section 7 of the QCS specifies that GSAS provides the foundation for green construction standards, and indicates that it constitutes a key reference resource. It goes on to provide more specific expectations with regard to energy (demand and efficiency in use of energy sources), water (consumption and burden on municipal systems), indoor environment (air quality, acoustics, light, and thermal comfort), cultural and economic value (cultural conservation and support of the local economy), management and operations, and materials (extraction, processing, manufacturing, distribution, use/reuse, and disposal).

Currently, only government new construction must comply with the green construction section. At some point, all new commercial and residential construction will be expected to comply. However, as of this publication no timeline has been established.

GSAS, which has been mandated under the QCS, was developed by the Gulf Organization on Research and Development (GORD). GORD studied best practices from 40 different sustainability rating systems to develop GSAS. Its primary objectives are to create a sustainable built environment that minimizes ecological impact, while addressing the specific social and cultural needs and environment of a particular region.

GSAS provides standards in eight categories: Energy (weighted at 24\%); Water (weighted at 16\%); Indoor Environment (weighted at 16\%); Site Selection (weighted at 13\%); Materials (weighted at $10 \%$ ); Cultural \& Economic Value (weighted at 7\%); Urban Connectivity (weighted at 7\%); and Management \& Operations (weighted at 7\%). ${ }^{83}$

The "Energy" category includes considerations such as the energy demand of buildings, efficiency of energy delivery, and the use of fossil energy sources that would result in harmful emissions and pollution. The "Water" category includes considerations such as consumption and associated burden on municipal supply and treatment systems. The "Indoor Environment" category addresses indoor environmental quality and thermal comfort, air quality, acoustic, and light quality. The "Cultural \& Economic Value" category addresses cultural conservation and support of the local economy.

The "Site" category focuses on land use (conservation, remediation; site selection, planning development). The "Urban Connectivity" category provides requirements for cultivating a vibrant urban environment through zoning, transportation networks, as well loadings related to traffic, air, noise, and light pollution. The "Materials" category deals with issues related to extraction, processing, manufacturing, distribution, use/re-use, and disposal. Finally, the "Management \& Operations" category focuses on building design management and operations issues, such as sub-metering of energy usage, leak detection, and commissioning.

Significantly though, the QCS only mandates adherence to the energy, water, indoor environment, cultural and economic value, management and operations, and materials categories. Also significantly, GSAS places relatively low weights for three key sustainability rubrics (urban connectivity, materials, and management \& operations), while placing a relatively disproportionate emphasis on cultural \& economic value. Given the emphasis in Qatari culture (and Arab culture in general) on preserving cultural heritage and supporting the economic wellbeing of its citizens, the latter category emphasis is understandable. However, the low priority given to maintenance \& operations constitutes a potential deficiency in the GSAS system, and thereby the QCS's incorporation. At the same time, it also presents an opportunity for policy makers, considering that much of the savings realized in a high-performance development project occurs during the active lifecycle of the building.

\section{Comparative Policy Options}

The purpose of this section is to detail several policy measures implemented in the UK to serve as case studies for effective practices. The section concludes by determining which policies would be most suitable for application in the context of Qatari legislation.

The United Kingdom has engaged with green fiscal reform in this sector in order to meet its renewable energy

83 “Technical Guide 2018," Global Sustainability Assessment System, p. 17,

http://www.gord.qa/admin/Content/Link116201825819.pdf(2018). 
targets, reduce emissions, and achieve energy independence. ${ }^{84}$ Pigovian ${ }^{85}$ environmental taxation and alternative fiscal tools to dissocialize negative environmental externalities ${ }^{86}$ were enshrined in the British Government's policies following the Stern Review, which determined that "putting an appropriate price on carbon...through tax...means that people are faced with the full social cost of their actions." ${ }^{87}$ It remains obliged to undertake measures to meet the EU Energy Efficiency Directive ${ }^{88}$ and the EU Energy Performance of Buildings Directive. ${ }^{89}$

Qatar has not yet engaged with such fiscal policies, and nationals are exempt from water and electricity costs. These conditions provide a perverse subsidy that encourages the waste of scarce resources, rather than encourage conservation.

\subsection{Existing Builds}

Existing residential homes in the United Kingdom consume over $25 \%$ of energy nationwide. As such, they have been an ideal target for green fiscal measures intending to reduce energy consumption. ${ }^{90}$

\subsubsection{Incentives}

The British Government's Green Deal is essentially a loan from approved "green finance" companies that householders repay through their electricity bill. ${ }^{91}$ The loan enables energy-saving improvements to be made to a home, such as insulation, heating, draft-proofing, and double glazing. It also provides opportunities for micro-production of renewable energy generation, such as solar panels or heat pumps.

In practice, the efficacy of the incentive proved to be limited because many private householders were concerned about getting into too much debt. And unfortunately, the government no longer funds the Green Deal Finance Company, which was set up to lend money to Green Deal providers. As a result, it is expected that there will be fewer options on the market in the future.

A more popular incentive has been the Feed-in Tariff, ${ }^{92}$ which enables householders to own a solar panel or wind turbine and receive payments from the energy supplier for generating their own electricity. An export tariff such as this enables the sale of surplus units back to the electricity supplier.

Such incentives encouraged upgrade investments, particularly in solar panels. Indeed, in 2014 the UK installed more solar power than any other European country. ${ }^{93}$ However, the Department of Energy \& Climate Change subsequently reduced the amount a small household could get from 12.47 pence per kilowatt hour to 1.63 pence, meaning it would take far longer to make the panels profitable.

There is also the Domestic Renewable Heat Incentive ${ }^{94}$ which provides up to seven years of payments to fund the switch to solar water heating, biomass boilers and some heat pumps in existing builds. ${ }^{95}$ Smart meters are required to be offered by all UK energy suppliers by $2020 .^{96}$

\footnotetext{
${ }^{84}$ Jon M. Truby, "Maritime Emissions Taxation: An Alternative to the EU Emissions Trading Scheme?,” 31 Pace Envtl. L. Rev. 310 http://digitalcommons.pace.edu/pelr/vol31/iss1/4 (2014).

${ }^{85}$ Arthur Cecil Pigou, Wealth and Welfare (London: Macmillan \& Co., 1912).

${ }^{86}$ See William Baumol "On Taxation and the Control of Externalities" 3 Amer. Econ. Rev. 62 (1972), pp. 307-22.

${ }^{87}$ Nicholas Stern, Stern Review: The Economics of Climate Change, p. xviii (London: CUP, 2007).

${ }^{88}$ Directive 2012/27/EU of the European Parliament and of the Council of 25 October 2012 on energy efficiency, amending Directives 2009/125/EC and 2010/30/EU and repealing Directives 2004/8/EC and 2006/32/EC Text with EEA relevance, OJ L 315, 14.11.2012.

${ }^{89}$ Directive 2010/31/EU of the European Parliament and of the Council of 19 May 2010 on the energy performance of buildings OJ L 153, 18.6.2010, pp. 13-35.

${ }^{90}$ Radwa Salem, Ali Bahadori-Jahromi, Anastasia Mylona, Paulina Godfrey and Darren Cook, "Retrofit of a UK Residential Property to Achieve Nearly Zero Energy Building Standard," Advances in Environmental Research, Vol. 7, No. 1 000-000 DOI: https://doi.org/10.12989/aer.2018.7.1.000 (2018).

91 “Green Deal: Energy Saving for Your Home," UK Government, https://www.gov.uk/green-deal-energy-saving-measures.

92 “Feed-in Tariffs: Get Money for Generating Your Own Electricity,” UK Government, https://www.gov.uk/feed-in-tariffs.

93 "UK Installed More Solar Power Than Any Other European Country in 2014," The Guardian, http:/www.theguardian.com/environment/2015/apr/28/uk-installed-more-solar-power-than-any-other-europeancountry-in-2014 (April 28, 2015).

94 “Domestic Renewable Heat Incentive (RHI)," OFGEM, https://www.ofgem.gov.uk/environmental-programmes/domestic-rhi.

95 "Domestic Renewable Heat Incentive (RHI)," UK Government, https://www.gov.uk/domestic-renewable-heat-incentive.

96 "How Will the Installation Happen?," Smart Energy, https://www.smartenergygb.org/en/smart-future/about-the-rollout.
} 


\subsubsection{Energy Performance Certificates}

The UK also has an Energy Performance Certificate ("EPC") system (see Figure [1]), which must be made available whenever a landlord rents out a property, a property is sold, or a new house is built. ${ }^{97}$ It bands the property according to its efficiency. ${ }^{98}$ Property advertisements to tenants are legally required to provide this rating. However, this only advises purchasers or potential tenants of the likely cost of utilities charges when renting. ${ }^{99}$

From 1 April 2018, it will not possible for landlords to rent out any property on a new lease with less than an "E" performance rating. This will be applied to all rental properties from 1 April 2020. Six percent of UK domestic properties and $18 \%$ of non-domestic property were rated $\mathrm{F} / \mathrm{G}$ in 2016 . This mandatory regulation will have a significant impact upon the housing stock, since properties rated " $\mathrm{F} / \mathrm{G}$ " will either be upgraded or removed from the housing stock if it is too expensive to do so. ${ }^{100}$ This creates a major incentive forboth existing landlords and buy-to-let investors to consider these ratings in their decision to purchase a property.

For properties falling outside of those bands however, the cost of upgrading is still considered too high by many landlords compared to the potential impact on tenants' demand for the property. This is particularly true in densely populated cities such as London, where tenancy demand is high and energy efficiency does not make a major impact on tenants' decisions of whether or not to rent.

Since the tenant pays the utilities cost and has an incentive to reduce it, since 2016 they have had the right to receive consent from the landlord (which cannot be unreasonably withheld) ${ }^{101}$ to upgrade the property with such energy efficiency improvements as provided in the Green Deal (Qualifying Energy Improvements) Order 2012. However, for the majority of assured short-hold tenancy agreements (which last from one to three years), it is unlikely that most tenants will be willing to make the necessary investment to complete the upgrade.

By 2020, the "Minimum Level of Energy Efficiency" standard will be band "E."102 Over time, the required level of banding to rent a property is expected to increase, which will encourage landlords to retrofit their existing properties.

Such a system could easily be implemented in Qatar. Currently, all privately rented properties must be registered with Qatar's Real Estate Lease Contracts Office. ${ }^{103}$ An annual registration fee of $0.5 \%$ of the annual rental value of the premises must be paid to that Office through the Minister of Municipality and Environment.

The existence of such a fee, with a minimum fee of 250 QAR and a maximum fee of 2,500 QAR, means that landlords are already accustomed to paying a fee and expect to do so. Currently, they have no incentive to invest in retrofitting. However, it would be relatively simple to vary the fee based upon the energy performance of the property following an inspection. As a result, landlords would have an incentive to achieve the lowest possible fee.

\footnotetext{
${ }^{97}$ The rules are set out pursuant to the Energy Performance of Buildings (England and Wales) Regulations 2012 (as amended) and the Building Regulations 2010.

98 "Buying or Selling Your Home," UK Government, https://www.gov.uk/buy-sell-your-home/energy-performance-certificates.

99 See also "A Guide to Energy Performance Certificates for the Marketing, Sale and Let of Dwellings, Department for Communities and Local Government,

https://www.gov.uk/government/uploads/system/uploads/attachment_data/file/671018/A_guide_to_energy_perf ormance_certificates_for_the marketing_sale_and_let_of_dwellings.pdf (2017).

100 "Private Rented Sector Minimum Energy Efficiency Standards and Tenants' Rights," Department for Business, Energy \& Industrial Strategy, https://www.aleo.org.uk/conferences/bournemouth-2016/downloads/stephen-ryman.pdf October 2016.

101 "Requesting Energy Efficiency Improvements," Residential Landlords Association, https://www.rla.org.uk/landlord/guides/requesting-energy-efficiency-improvements.shtml.

102 The Energy Efficiency (Private Rented Property) (England and Wales) Regulations 2015.

${ }^{103}$ Law No. 19 of 2017, amending some provisions of Law No. 4 of 2008 on Real Estate Leasing.
} 


\section{Energy Efficiency Rating}

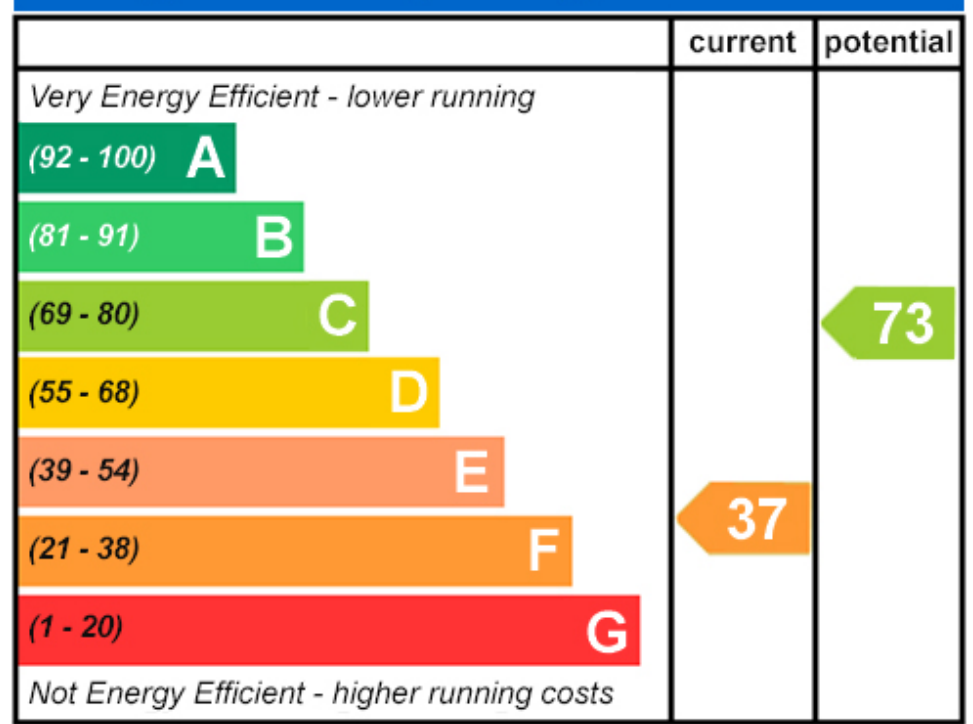

Figure 1. UK energy performance certificate system

\subsubsection{Council Tax and Vehicle Excise Duty}

There have been proposals to incorporate the EPC rating into the UK's council tax system, which is a local or municipal property tax to fund local services. This is a progressive tax system based on estimated value of property. However, the bandings are based on estimated valuations from 1991 and have not been adjusted since then.

Aside from being socially distributive by charging higher rates of council tax for more expensive properties, it is ineffective at being a measure to alter environmental behavior. The UK's Green Building Council proposed variable rates of council tax to incentivize retrofit based upon the EPC. The revenue-neutral model proposed therein had some limitations but was estimated to potentially save $1,123,716-2,231,594$ tCO2 annually. ${ }^{104}$

Such a switch would replace the property value-based system with a system promoting energy efficiency, rewarding households that invest in energy efficiency, and charging on a polluter-pays approach for those who continue to operate highly inefficient households. This fiscal reform solution would provide an incentive to make the required changes for the end user who actually pays the council tax and could influence a renter's property preferences. Shifting demand for more efficient properties would ultimately undermine demand for inefficient properties. The revenue gained could also be used to help lower income households make necessary improvements needed so that there were no negative impacts on welfare.

104 “Retrofit Incentives,” UK Green Building Council (July 2013), at p. 49. 


\begin{tabular}{|c|c|c|c|}
\hline Band & $\begin{array}{c}\text { Tax rate relative to } \\
\text { Band D }\end{array}$ & $\begin{array}{c}\text { Property valuation as } \\
\text { of } 1 \text { April } 1991\end{array}$ & $\begin{array}{c}\text { Distribution of } \\
\text { dwellings by band (\%) }\end{array}$ \\
\hline A & $2 / 3$ & Up to $f 40,000$ & 24.7 \\
\hline B & $7 / 9$ & $£ 40,001$ to $f 52,000$ & 19.6 \\
\hline C & $8 / 9$ & $f 52,001$ to $f 68,000$ & 21.8 \\
\hline D & 1 & $f 68,001$ to $f 88,000$ & 15.3 \\
\hline $\mathrm{E}$ & $12 / 9$ & $f 88,001$ to $f 120,000$ & 9.4 \\
\hline $\mathrm{F}$ & $14 \%$ & $£ 120,001$ to $£ 160,000$ & 5.0 \\
\hline G & $12 / 3$ & $f 160,001$ to $f 320,000$ & 3.5 \\
\hline H & 2 & Above $\mathrm{f} 320,000$ & 0.6 \\
\hline
\end{tabular}

Source: Department for Communities and Local Government, Local Authority Council Taxbase 2013 England,

https://www.gov.uk/government/uploads/system/uploads/attachment_data/file/285659/Revis ed_Local_authority_Council_Taxbase_England_2013.pdf.

Figure 2. Value Bands for England, September 2013

The British government has not currently proceeded with this recommendation, potentially due to a fear of losing revenue if the scheme is too successful. Instead, a regulatory approach has been adopted which utilizes the EPC to prevent the letting of privately rented properties to tenants of properties in lower bands of energy efficiency. ${ }^{105}$ That said, it is quite possible to carry out such a program in a revenue neutral way similar to the Vehicle Excise Duty.

The Vehicle Excise Duty currently bands vehicles according to their $\mathrm{CO} 2$ emissions and charges tax each year based on those bands. If you own an electric vehicle or low emissions vehicle you pay zero or very little tax, and in line with the "polluter pays" principle, if you own a large polluting SUV you will pay higher rates of tax each year. This creates an incentive for motorists to invest in cleaner cars, and it has been working. After the first year, electric vehicles are charged no tax. This could similarly happen with council tax using the EPC.

First Tax Payment Upon Registering the Vehicle:

$\mathrm{CO} 2$ emissions (g/km) Petrol (TC48) and diesel cars (TC49) Alternative fuel cars (TC59)

$\begin{array}{ccc}0 & £ 0 & £ 0 \\ 1-50 & £ 10 & £ 0 \\ 51-75 & £ 25 & £ 15 \\ 76-90 & £ 100 & £ 90 \\ 91-100 & £ 120 & £ 110 \\ 101-110 & £ 140 & £ 130 \\ 111-130 & £ 160 & £ 150 \\ 131-150 & £ 200 & £ 190 \\ 151-170 & £ 500 & £ 490 \\ 171-190 & £ 800 & £ 790 \\ 191-225 & £ 1,200 & £ 1,190 \\ 226-255 & £ 1,700 & £ 1,690 \\ \text { Over } 255 & £ 2,000 & £ 1,990\end{array}$

Figure 3. Vehicle Excise Duty Rates

${ }^{105}$ The Energy Efficiency (Private Rented Property) (England and Wales) Regulations 2015. 


\subsubsection{Stamp Duty Land Tax}

Stamp Duty Land Tax ("SDLT") is charged when property is sold based on a percentage of the sale value pursuant to the Stamp Duty Land Tax Act 2015 and relevant Finance Acts. ${ }^{106}$ The UK Green Building Council recommended reducing SDLT for energy efficient homes, in order to create an incentive to upgrade the property prior to sale. ${ }^{107}$ This could be in line with the EPC. To minimize the tax (or decrease it from a higher rate of tax if the property was very polluting) there would be a larger incentive to spend the money prior to sale in order to avoid a large tax bill for the purchaser, who would otherwise be discouraged from buying the property.

The proposal was again revenue-neutral with a carrot-and-stick approach, providing "the possibility of having discounts for better-than-average properties alongside a premium for those performing less well...." ${ }^{108}$ However, this approach has not been taken up HM Treasury, which has been a missed opportunity since it was proposed in 2013. Millions of tons of carbon emissions could have been saved without any cost to the taxpayer.

In Qatar, property ownership is registered by the State, so any sale and purchase must be registered. It would be highly feasible to introduce a stamp duty similar to that proposed by the UK's Green Building Council, with variable duties payable depending upon the energy efficiency of the property. This could require an official inspection and evaluation of the property to determine its banding, which would encourage retrofit.

\subsection{New Builds}

For builders of new homes, there are some (albeit limited) requirements to construct low emissions homes and encourage micro-production of renewable energy in order to reduce dependence on fossil fuels. ${ }^{109}$ Building regulations tend to be utilized in the UK to achieve this.

\subsubsection{Further Policy Reform}

Policy is continuing to develop with regard to UK housing standards, with a recognition that inefficiency in housing design is costly, wasteful, and harmful. The opposition Labor Party's manifesto includes a policy to introduce a "zero carbon homes standard for new-build homes," upgrading four million homes to a higher Band C EPC, insulating homes, and expanding the installation of solar energy panels on homes for micro-production. ${ }^{110}$ Although initially expensive, this would have a significant impact on the average UK household's energy efficiency and go far towards reducing its national emissions.

Recognizing that buildings consume $40 \%$ of energy in the EU, ${ }^{111}$ the European Commission has also recently voted on new measures to improve energy efficiency in buildings through revisions to the Energy Performance of Buildings directive ${ }^{112}$ and the Clean Energy for All Europeans ${ }^{113}$ package, including the Smart Finance for Smart Buildings Initiative which focuses on sustainable investment. ${ }^{114}$ Such rules and policies may continue to apply following the UK's possible departure from the EU.

The UK's Green Building Council March 2019 report ${ }^{115}$ advocates for adherence towards the World Green

\footnotetext{
106 “Stamp Duty Land Tax,” UK Government, https://www.gov.uk/stamp-duty-land-tax.

107 “Retrofit Incentives,” UK Green Building Council, at p. 20 (July 2013).

${ }^{108}$ Id.

109 See also WeiPan and Helen Garmston, Compliance with Building Energy Regulations for New-Build Dwellings, Energy 48(1), at pp. 11-22 (2012); Emma Heffernan, Wei Pan, Xi Liang, Pieter de Wilde, Zero Carbon Homes: Perceptions from the UK Construction Industry, Energy Policy (79) at pp. 23-36 (2015).

110 “The Green Transformation: Labour’s Environment Policy,” UK Labour Party,

https://www.labour.org.uk/wp-content/uploads/2018/09/The-Green-Transformation-.pdf.

111 "Press Release: Commission Welcomes Final Vote on Energy Performance of Buildings," European Commission, Brussels, http://europa.eu/rapid/press-release_IP-18-3374_en.htm (April 17, 2018).

112 Energy Performance of Buildings Directive (EU) 2018/844 OJ (L156).

113 "Clean Energy for All Europeans Package," European Commission, Brussels, https:/ec.europa.eu/energy/en/topics/energy-strategy-and-energy-union/clean-energy-all-europeans (September 16, 2019).

114 "Smart Finance for Smart Buildings: Investing in Energy Efficiency in Buildings," European Commission, Brussels, https:/ec.europa.eu/info/news/smart-finance-smart-buildings-investing-energy-efficiency-buildings-2018-feb-07 en (February 7, 2018).

115 "Leading the Way: Industry Trends, Commitments and Best Practice Examples," UK Green Building Counsel, https://www.ukgbc.org/wp-content/uploads/2019/02/UKGBC-Leading-the-Way-2019-1.pdf (March 2019).
} 
Building Council's Advancing Net Zero commitment. ${ }^{116}$ This works on a target commitment followed by transparency and reporting basis similar to the 2015 Paris Agreement. It has ambitious targets that all new buildings would be carbon neutral by 2030 , and all existing buildings would be by 2050 . To do this, it requires micro-production of renewable energy from the building, accompanied by a highly efficient design and metrics to assess the building's energy performance.

Similar commitments could be adopted by the State of Qatar. Adherence to such commitments in Qatar would focus planning towards more efficient building design and energy efficiency.

\section{Conclusion and Policy Implications}

Qatar's laws and policies indicate a desire to reduce emissions in buildings and promote energy efficient "green" building standards. Its buildings, as in other countries, are a major source of energy consumption and emissions, hindering progress towards the Nationally Determined Contributions agreed in the Paris Agreement. As its seeks sustainable development while its emissions continue to grow, there are several options by which Qatar can encourage the reduction of emissions in its housing and commercial property stock.

Many of these are simple measures seen elsewhere. For example, automated lighting and climate control currently consumes and wastes substantial sums of energy even in long-term vacant buildings. Additionally, installation of solar panels and smart meters on every building would be straightforward but could yield considerable results. And finally, electronic monitoring of energy usage in properties could be incorporated using smart meters.

Some of these measures would come from cost concerns. However, due to circumstances such as energy subsidies, many options are unlikely to be considered or implemented without top-down enforcement. Measures focused upon tenants in Qatar would likely have little effect compared to the potential for measures focused upon builders of new homes or existing landlords to encourage upgrades.

Since landlords of privately rented accommodation are charged a fee upon the registration of a tenancy agreement, ${ }^{117}$ it would prudent as highlighted above to make the fee variable based upon the proven energy performance of the property. The existence of this fee means that landlord are already required to pay a form of property tax, and are subject to punishment for illegally letting without registration. It is recommended that a property inspection take place by an authorized Ministerial department prior to the tenancy registration in order to assess and verify a property's energy performance rating. This official evaluation would be submitted at the time of registration, with premiums charged for less energy efficient properties and discounts for more energy efficient properties. The fees should increase over time for less efficient properties. These measures would go far towards encouraging retrofit by landlords by making it less cost effective to rent out low efficiency properties.

Subsidy reforms may work more effectively in the short term to ensure costs are a concern when deciding on building design and consumption. The energy performance certificate method adopted by the UK would be possible to replicate for existing buildings and upon property sales, with a requirement for an increasingly high level of performance. Given that the Qatari executive branch can pass legislation (or encourage legislation to be passed) relatively easily, increasing mandatory standards would be a straightforward task.

LEED ${ }^{\circledR}$ certified buildings for new buildings would perhaps be the most suitable for Qatar given that they offer a tested, straightforward, achievable, and non-market-based means of rapidly improving new buildings. It is also vital that existing building stock be upgraded to adapt to similar standards to achieve overall reductions. For new builds, a top-down mandatory approach would be the most effective approach to ensure total compliance. Finally, a commitment towards the World Green Building Council's Advancing Net Zero commitment would be advisable to reach best practices.

\section{Copyrights}

Copyright for this article is retained by the author(s), with first publication rights granted to the journal.

This is an open-access article distributed under the terms and conditions of the Creative Commons Attribution license (http://creativecommons.org/licenses/by/4.0/).

\footnotetext{
116 "From Thousands To Billions," World Green Building Council, https://www.worldgbc.org/sites/default/files/From\%20Thousands\%20To\%20Billions\%20WorldGBC\%20report_FINAL\%20issue\%2031051 7.compressed.pdf.

${ }^{117}$ Law No. 19 of 2017, amending some provisions of Law No. 4 of 2008 on Real Estate Leasing.
} 